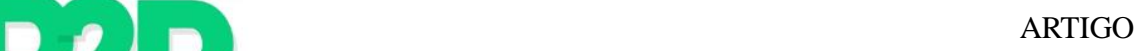

\title{
THE SOCIAL CAPITAL STRUCTURE IN THE CONTEMPORARY FINE ARTS FIELD: THE LEGITIMATION AND PRESTIGE LOGICS IN THE POWER 100 EGO NETWORKS
}

\author{
Débora Salles \\ $\mathrm{PhD}$ student at Federal University of Rio de Janeiro (UFRJ), School of Communication. \\ Information Science Graduate Program. Email: debora.g.salles@gmail.com \\ Rose Marie Santini \\ Profesor at Federal University of Rio de Janeiro (UFRJ), School of Communication. \\ Information Science Graduate Program. Email: marie.santini@eco.ufrj.br
}

\begin{abstract}
This article analyzes social relations among the most influential people in the contemporary art field. It tests the hypothesis of whether commercial connections can be an index of the relations of influence and legitimacy in the visual art world and whether these relations affect the cultural capital they possess and the position they occupy in the field. The Power 100 ranking - a guide to the most influential figures in contemporary art - and the commercial relations among the people listed were used to design six ego networks. Data regarding the social connections was collected from the Artsy online platform. The article identifies the mechanisms of social legitimation and artistic influence, as well as the cultural and social implications of social networks in the contemporary artistic field, now perceived in digital environments.
\end{abstract}

Keywords

Ego-network. Art field. Social capital. Cultural legitimation. Prestige. Power 100.

\section{A ESTRUTURA DO CAPITAL SOCIAL NO CAMPO ARTÍSTICO CONTEMPORÂNEO: AS LÓGICAS DE LEGITIMAÇÃO E PRESTÍGIO NAS REDES EGO DA POWER 100}

\section{Resumo}

Este artigo analisa as relações sociais entre as pessoas mais influentes no campo da arte contemporânea. Ele testa a hipótese de as ligações comerciais poderem ser um índice das relações de influência e legitimidade no mundo das artes visuais, e se essas relações afetam o capital cultural que essas pessoas possuem e a posição que ocupam no campo. O ranking Power 100 - um guia das figuras mais influentes na arte contemporânea - e as relações comerciais entre as pessoas listadas foram usados para criar seis redes ego. Dados relativos às conexões sociais foram coletados na plataforma on-line Artsy. O artigo identifica os mecanismos de legitimação social e influência artística, bem como as implicações culturais e sociais das redes sociais no campo artístico contemporâneo, agora percebidos em ambientes digitais.

Palavras-chave

Rede ego. Campo da arte. Capital social. Legitimação cultural. Power 100. 


\section{INTRODUCTION}

The fine arts field is a symbolic system that works simultaneously as a mechanism for knowledge and information and as a legitimizing instrument for the existing order. For the sociologist Pierre Bourdieu (2008; 2011), the field is based on strategic competition that consecrates and validates works of art, museums, galleries, artists, collectors, and so on. The members of the field seek to accumulate cultural, social, and economic capital. The power relations among these competitors shape a network of aesthetic and economic influence (DiMaggio, 2011).

Although the theory proposed by Bourdieu and his followers focuses on different cultural products and fields, it has not covered directly the contemporary fine arts world or its social networks structure. Also, the fine arts world has undergone several changes in the past decades, and its social dynamic has not been fully investigated. The relational approach to contemporary art has also been overlooked.

This study gives attention to the organizational arrangement of the fine arts field, as well as its own logic of symbolic domination. Therefore, we are interested in investigating the selection and validation processes of the people, the institutions, and the works of art. Our aim is to analyze to what extent the relations among the most influential people in the art world secure, in some way, their position in the field. We test the hypothesis that the most powerful people in the arts are necessarily closely connected with each other.

As our case study, we use the Power 100 ranking, a yearly survey composed by the Art Review magazine, which puts together the most influential and powerful figures in the art world. This list is a combination of different art professionals, such as art fair directors, collectors, curators, gallerists, and artists. We have used the information from the latest available ranking to design ego-networks that can work as a sample of the social relations engendered in the field. In order to do so, we have used the database available on the Artsy website. The connections indicated by the online platform are then used to frame the social networks in the contemporary fine arts field.

This article is organized as follows: in the next section, we review some theoretical proposals linking the field of cultural production and its social relations. We go on to present the method and test the hypotheses, and then present the results followed by a discussion and concluding comments. 


\section{LITERATURE REVIEW}

The relational perspective of culture can be associated with formally organized systems that produce and distribute cultural products through the collaboration of networks composed by both people and organizations . Cultural products are defined here as "discrete and apprehensible human creations - songs, paintings, newspaper articles, meals, sermons, laws, poems, scientific papers, garments - associated with institutionalized fields of cultural productions".

Howard Becker $(1977,2008)$ conceives these cultural systems as collaborative networks called "artworlds," which consist of sets of people and organizations that produce the events and objects defined by that same world as "art." Therefore, social studies on cultural production should identify the people, organizations, and institutions collaborating to produce and distribute the cultural goods they, at least, call art.

In order to study the cultural production and the people involved in these spheres, we should take into account all the activities that were carried out in order for any work of art to become what it is. The individual creators, such as the artists, are just one of the groups of people embedded in these systems. In the fine arts systems, for example, there are other occupations and institutions involved, such as gallerists, curators, collectors, auction houses, museums, art fairs, art critics, art historians, schools, advisers, foundations, and the public.

Becker $(1977,2008)$ considers works of art and their value as the result of coordinated actions of all the people whose cooperation is needed to have the work produced, distributed, classified, and consumed the way it is. Any social value assigned to a work of art or to an artist has its origin in organized artworlds. The interaction of all parties involved in the system produces a common sense of value of what is produced by them collectively. The mutual appreciation of shared conventions, and the support each person or organization gives each other, convinces them that it is worth doing what they do and that the product of their efforts is valid.

These collaborative networks establish conventions that cover all decisions concerning the production, distribution, and classification of cultural goods. These agreements include all the appropriate features for the works and their consumption, as well as their dimensions, the way they should be exhibited, or even sold. Pierre Bourdieu $(1993,2008,2011)$ has a similar approach to the production of cultural goods. But while Becker emphasizes consensus and the act of 
collection, Bourdieu gives greater emphasis to the conflicts and competitions for power among the agents in cultural systems. ${ }^{1}$

For Bourdieu (1980), in the belief production process that supports the economy of cultural goods, the only useful and efficient capital corresponds to what the author calls "prestige". As "cultural authority", prestige can only guarantee specific gains produced by the field if it is converted into symbolic capital. In other words, it is a matter of accumulating "recognition capital" which leads to a power of legitimizing productions or people through judgments and classifications - and, therefore, giving value to and obtaining benefits from this operation in a given field or market.

When selecting and reporting the value of symbolic goods by disseminating opinions and suggestions, the mediators act as "symbolic bankers" (Bourdieu 1980, p. 262); that is, as "guarantors of the quality of the works", offering their public, audience or readers their accumulated wealth of symbolic capital as guarantee of the validity of the information and suggestions conveyed. This guarantee corresponds to the principal investment that drives the Cultural Industries market and that allows their products to penetrate the cycle of recognition and major economic return.

However, the fight for appropriation of "recognition capital" in the cultural field is not sufficient to sustain the strong participation of its mediators. According to Bourdieu (1985), the struggle for symbolic power occurs in parallel to those agents' inherent need to accumulate economic capital. Although they depend on the prestige of others to consecrate themselves, they compete to accumulate the most authority. This dual imperative, which is often contradictory in the artistic and cultural field, has been instigating a profound change in the recommendation spaces.

Bourdieu defines the field of artistic production as "the system of objective relations between these agents or institutions and as the site of the struggles for the monopoly of the power to consecrate, in which the value of works of art and belief in that value are continuously generated" (Bourdieu, 1980, p. 265).

In order to develop a general theory of social classes and their distinguishing criteria, Bourdieu (2011) states that the differences are not based only on economic disparities, but also on

${ }^{1}$ This article embraces both approaches, since the art system, like other cultural spheres, is intersected by general agreements and disputes. 
other types of differentiation. In this sense, he tries to make evident the existence of a distinction system through the acquisition and appropriation of cultural capital. Cultural capital is a nonfinancial asset that guarantees social privileges beyond the economic gains. This requires a specific capital investment and reflects standards and skills valued by the dominant social stratum. These aesthetic and social standards are understood and enforced as the legitimate culture.

Cultural fields operate as a trade activity based on economic denial; their operation is based on a "collective denial of interests and commercial gain". However, there is a disguised economic rationality, so that successful agents can recognize the demands and requirements of the field by exploiting a useful capital: prestige. Therefore, symbolic capital is a trading currency in this field and the only legitimate accumulation is consecration. Symbolic capital gains may or may not generate economic profits, but they are already a goal in itself.

The difficulty in understanding value production in the cultural and artistic fields is due to the operation of its own ideology. There is a widespread belief that the value of cultural goods is established based on their apparent producer: the creator. This conviction prevents us from investigating who gives voice to the author, or who confers the authority that this author acquires.

Hence, an artistic work or object does not have an intrinsic value, since it is socially constructed from the prestige of the author of the work in question. The symbolic capital of the already established agents is loaned. It functions as a passport to the consecration cycle of select social groups in which the art dealers, critics, journalists and experts already circulates and has social relations.

The art merchant's authority comes from an exchange of interests. The art dealer's influence is his or her symbolic capital, functioning as credit within a group of agents (Bourdieu, 2008). To strengthen the authority of these "symbolic bankers" and the consequent appreciation of a work, the critics' collaboration is essential, since their advice guides both buyers and sellers. Customers also add value to the work, since they affirm its value by appropriating it in the same way that cultural goods identify a part of consumer value.

Inasmuch as cultural goods have a specific logic of production, distribution, and consumption, social distinguishing criteria are constructed through the taste for and the ownership of exclusive and intellectualized cultural products. These goods are able to classify individuals within the society, since they identify and reproduce the class structure and therefore 
are central to the sociological analysis of culture. To sum up, the creation, circulation, consecration, and consumption of certain goods are social operations that result in social distinction and are managed by a cultural elite.

The elite agents are, therefore, able to consecrate and legitimate products. They have the symbolic power and the cultural capital to distinguish between art and entertainment, between high culture and mass products. Art is traditionally distributed by not-for-profit organizations, managed by artistic professionals, and governed closely by prosperous and influential trustees, whereas popular entertainment is sponsored by entrepreneurs and distributed via the market to whoever will buy it. Consequently, these elite networks are able to segregate and institutionalize specific cultural practices and goods through social relations and economic resources.

Paul DiMaggio addressed one classic example of these mechanisms: how prestigious institutions emerged in late nineteenth-century Boston. These cultural establishments were the result of a conscious action by an elite who used its densely connected social relations to govern, sponsor, and staff the artistic institutions it created. This social network was based on kinship, commerce, club membership, and participation in a wide range of philanthropic associations. These were organization-forming status groups, since they were clustered on the private, educational, commercial, social, and cultural levels. Naturally, these organized relations granted status to the participants, at the same time that they earned their prestige from their members. The process of creating and institutionalizing high culture demanded entrepreneurship, classification, and framing:

By entrepreneurship, I mean the creation of an organizational form that members of the elite could control and govern. By classification, I refer to the erection of strong and clearly defined boundaries between art and entertainment, the definition of a high art that elites and segments of the middles class could appropriate as their own cultural property; and the acknowledgment of that classification's legitimacy by other classes and the state. Finally, I use the term framing to refer to the development of a new etiquette of appropriation, a new relationship between audience and the work of art."

DiMaggio calls the people involved in the definition and institutionalization of high culture (and its opposite) cultural capitalists. Their wealth and profit came from industrial enterprises and the cultural investments were made from these resources. They were also representative of the cultural capital examined by Bourdieu. The members of these organizations possessed knowledge and familiarity with legitimated and prestigious artistic products and practices. 
In this sense, value in the art field is the product of a cycle of symbolic consecration. Since it is a social construction, the distinctive character of a cultural product is not linked to its intrinsic value, since agents with symbolic capital are responsible for the prestige that construct this value. Agents involved in the production, distribution, and consumption of a certain cultural field are "guarantors" of authority among each other and construct a belief structure in symbolic value. Thus, cultural fields are systems of relations among social actors fighting for the monopoly of consecration power and symbolic assignment. These struggles assign social value to the construction of a product.

Cultural fields are sites where actors with different degrees of cultural capital and economic resources compete. Apart from cultural fluency and financial means, social capital also plays an important role in defining one's position and status in a given field. The amount and composition of economic and cultural capital an actor owns influence the social relations he can establish. These relations, in turn, affect the returns from alternative creative strategies .

The relational theories of artworlds and cultural fields focus on the set of relations among all agents involved in the cultural system. Organizations, artists, the public, and so on, are all engaged in the production, distribution, and use of cultural products or of the social value of these goods. These notions also cover the social collaborations and initiatives that guarantee the classification of an artwork as such.

Therefore, strategies to "create" (or stabilize) the belief and the desire of so-called cultural products are shaped by mechanisms of social control and involve elements of constraint, enforcement, stimulation and seduction, however their power and applicability are not immutable across different times, locations and contexts. Cultural habits are only created and disseminated as a result of a complex and contradictory process against the strategies of competitors in the market with the wishes, expectations, hopes and points of resistance of the consumers. This is how the demand holds structural sway on the supply; by way of acceptances or rejections of the proposed solutions in terms of production, forcing adjustments and changes on the supply side. Thus, adapting the ways to stimulate demand is a key issue in the new spheres of consumption; and this is now being perceived in the digital environments. 


\section{METHOD}

The Power 100 ranking has been published by the British magazine ArtReview ${ }^{2}$ since 2002 and comprises a yearly ranking of the most influential and powerful people in the art world. It intends to be a guide to the often-invisible structures and forces driving the international contemporary art scene. ${ }^{3}$ The list is an attempt to disclose the operations within the art system. The selection is based on four criteria: 1) affecting the kind of art being currently produced; 2) being active in the last twelve months; 3) having international, rather than a local, impact; and 4) influencing the public perception of what art is, and not just operating and being influent within the art system. The weight and relevance of these criteria, however, are not public.

An anonymous committee of individuals based in places such as Delhi, Shanghai, Beijing, New York, Los Angeles, Mexico City, Sao Paulo, Dubai, Paris, Berlin, Milan, and London determines the ranking. These individuals should represent the globalized and complex ecosystem of the contemporary art field. Most of the consultants have been on previous panels or were themselves indicated by the ranking within the past years. Each member on the committee reports on the figures from their own territory.

Initially, we examined the basic information data on the people and institutions in the Power 100, such as nationality, gender, and place of work or residence (Appendix 1). Regarding the figures' nationality, there is a preponderance of native Europeans and North Americans. British, Germans, and Americans together count for almost half of the ranking. Asians are also represented on the list, although no country by itself has any particular prevalence. Men are the vast majority in the ranking. According to the ArtReview Editor-in-Chief, gender issues do not come into play since this perspective could bias the main purpose of the list. Hence, this shows that men heavily control power in the art world.

There is a clear concentration of European and North American cities as choices for residency, work, or commercial presence. Although Asian locations are also significant, the main institutions present in these cities are branches from Western organizations. Among the 56 cities

\footnotetext{
${ }^{2}$ ArtReview is an international contemporary art magazine founded in 1949 in London. It features reviews of international exhibitions, artists' profiles, critical texts, city art-tour pieces, and artistic projects. Its goal is to expand contemporary art's reach and it is aimed at a specialist and a general audience. Two special annual features are included: Future Greats, a selection of promising emerging artists, published in the March issue; and the Power 100, published in November. In 2013, a sister magazine ArtReview Asia was launched. It covers worldwide art form an Asian perspective. It is distributed throughout Asia and is published in English.

${ }^{3}$ See: http://artreview.com/about us/. Access in $20^{\text {th }}$ Dec 2015.
} 
listed, the five most recurrent account for $49 \%$ of all art locations. New York, London, and Paris have traditionally fought for the world's art capital status . Berlin, however, has achieved notoriety in recent years and comprises the most amount of artists.

In order to examine the relations among the art figures, we generated ego-networks based on the question: with whom does this figure have professional relations? We randomly chose one person in the ranking (David Zwirner) and built his one-step ego network. We used the Artsy database to retrieve this information. The Artsy ${ }^{4}$ platform is the biggest online database of contemporary art. The archive comprises 357,317 works of art by more than 40,000 artists. ${ }^{5}$ The site counts on over 600 gallery partners who upload and update the profiles and artworks. It covers art world events such as exhibitions at museums, galleries, and biennials. It also previews international art fairs and hosts benefit auctions.

The platform also works as a search engine that draws connections and relations among works of art, artists, galleries, museum collections, art fairs, auctions, and private foundations. These connections can be related to past, present, or future exhibitions, aesthetic influence, and commercial representation. The sorts of connections available on the website are reciprocal, so we used un-directed ties to construct the network. Since Artsy focuses on the art market and its operations, the majority of people and institutions listed on Power 100 are present on the website (Table 1).

\begin{tabular}{|c|c|c|c|}
\hline & Power 100 & Artsy Datahase & Presence in datahase \\
\hline Artists & 25 & 25 & $100 \%$ \\
\hline Gallerists & 27 & 24 & $89 \%$ \\
\hline Museum Director & 12 & 9 & $75 \%$ \\
\hline Collector & 15 & 8 & $53 \%$ \\
\hline Curator & 14 & 7 & $50 \%$ \\
\hline Art Fair Director & 2 & 2 & $100 \%$ \\
\hline School Director & 2 & 0 & $0 \%$ \\
\hline Philosopher & 1 & 0 & $0 \%$ \\
\hline Website & 1 & 1 & $100 \%$ \\
\hline Foundation Founder & 1 & 0 & $0 \%$ \\
\hline Total & 100 & 76 & $76 \%$ \\
\hline
\end{tabular}

\footnotetext{
${ }^{4}$ Created by Carter Cleveland (\#94 on ArtReview Power 100) in 2010, Artsy is supported by a group of investors and advisors who also figure on the ArtReview list, such as Dasha Zhukovka (\#97), Larry Gagosian (\#6), and Marc Glimcher (\#23).

${ }^{5}$ https://www.artsy.net/about
} 
Following the design of David Zwirner's ego-network, we repeated the procedure with the alters of the first graph (Isa Genzken, Luc Tuymans, Wolfgang Tillmans, Yayoi Kusama, and Jeff Koons). This totaled six one-level ego networks, which were analyzed and compared, and later consolidated into a two-level ego network of the gallerist. Using Gephi software we extracted both measurements and graphs of the network.

\section{RESULTS}

Artsy links works of art mainly through sellers and buyers and the focus of the archive is to make the art pieces available online for educational and commercial purposes. Due to the database characteristics and the primary egos' occupation (gallerist), there is, in the sample, a slight prevalence of artists and an absence of non-related market categories, such as philosophers and school directors. This, however, does not decrease the sample's representative potential. The ego-networks cover $28 \%$ of the Power 100 figures in the Artsy database and $21 \%$ of the people ranked on the list. Its nodes also comprise the major occupational categories of the original selection (Table 2).

Table 2 - David Zwirner Two-Level Ego Network Nodes

\begin{tabular}{|c|c|}
\hline Gallerist $(n=5)$ & $\begin{array}{r}\text { David Zwirner; Iwan \& Manuela Wirth; Tim Neuger \& Burkhard } \\
\text { Riemschneider; Daniel Buchholz; Larry Gagosian }\end{array}$ \\
\hline Artist $(n=8)$ & $\begin{array}{l}\text { Isa Genzken; Luc Tuymans; Wolfgang Tillmans; Yayoi Kusama; Jeff } \\
\text { Koons; Christopher Wool, Cindy Sherman; Ai Weiwei }\end{array}$ \\
\hline Curator $(n=2)$ & Beatrix Ruf; Okwui Enwensor: \\
\hline Art Fair Director $(n=1)$ & Matthew Slotover \& Amanda Sharp \\
\hline Museum Director $(n=2)$ & Hans Ulrich Obrist \& Julia Peyton-Jones; Adam Weinberg \\
\hline Collector $(n=3)$ & François Pinault *; Bernard Arnault; Eli \& Edyth Broa \\
\hline \multicolumn{2}{|l|}{ Nodes $(n=21)$} \\
\hline $\begin{array}{l}\text { *François Pinault is both } \\
\text { categorized as a collector, }\end{array}$ & $\begin{array}{l}\text { nd the director of Christie's auction house. In the ranking he is } \\
\text { etwork he appears as an Art Fair director, since the connections }\end{array}$ \\
\hline
\end{tabular}

The artists are represented by several galleries, the only exception being Luc Tuyman. This kind of connection is the most common one and the primary source of social relations. Isa Genzken, for example, is represented simultaneously by four different figures. We suggest that 
these relations are even wider than can be traced. Thus, the gallerists carry out a vital activity for the field: they are the main power movers for the artists and the most powerful players, determining who gets a chance to exhibit, sell, or participate in the art field.

Being part of private collections (Bernard Arnault, Fondation Loius Vitton; Eli \& Edyth Broad, The Broad) also increases the social capital of the artists, and by default, of the galleries that represent them. Likewise, possessing works by prestigious artists grant legitimation and esteem to the collections. One interesting example is the opening of The Broad in Los Angeles on September 20, 2015. It is the first time the collection by Eli and Edyth Broad will be shown to the general public, covering 250 works by over 60 artists. The Inaugural Installation features pieces from Jeff Koons, Yayoi Kusama, and Cindy Sherman, and was promoted in Artsy through an enthusiastic article that anticipates the endeavor's success and importance.

The museum collections (Hans Ulrich Obrist \& Julia Peyton-Jones, Sepertine Galleries; Adam Weinberg, Whitney Museum) are not completely available in the database, so the relations among museum directors and artists do not appear to be significant in this survey. In spite of this absence, museum collections also play an important role in the operational logic of social capital. Although museums rely deeply on patrons and private collectors for donations and special exhibitions, for these networks, this sort of connection was not traceable through Artsy. 
Figure - David Zwirner's two-step ego-network

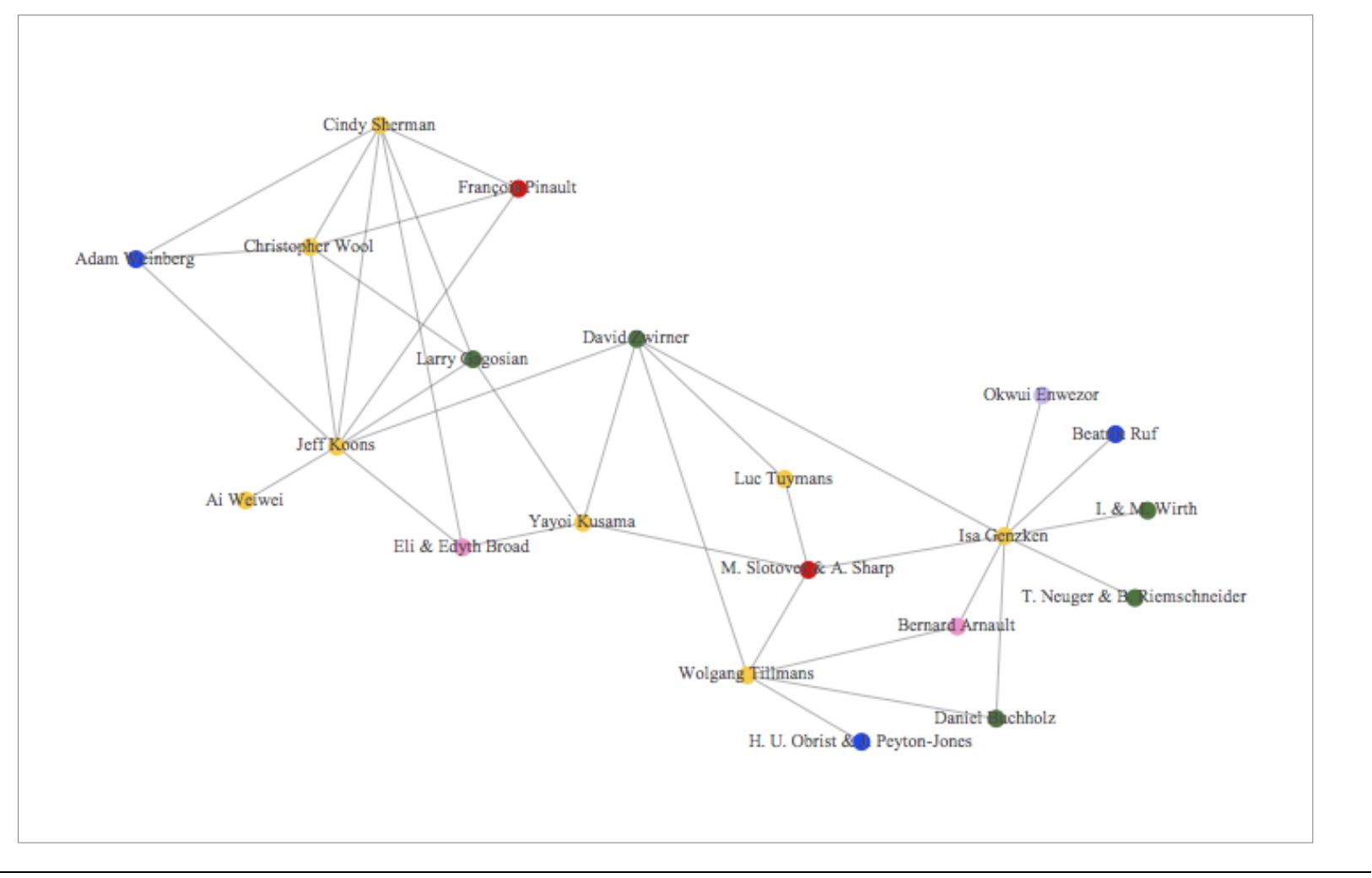

The art fairs and auctions (Matthew Slotover \& Amanda Sharp, Frieze Art Fair; François Pinault, Christie's Auction House) are relevant and appear in all artists' ego-networks. Besides the social capital embedded in the trade activity, they also ensure worldwide visibility and financial gain for the participants. The last type of connection found was the artist-artist type, that indicates aesthetic similarity, being shown together in an exhibition or participating in the same auctions.

Regarding the basic size, distance, and density measures (Table 3), Isa Genzken and Jeff Koons have the biggest ego-networks, while Luc Tuymans has the smallest and densest (0.667). Genzken is embedded in the least tight structure. Koons, however, has the most connected personal web with 16 ties. Since most networks do not have ties between alters, degree and average path length are equal. Koons is in the only ego network that has any kind of clustering and has the highest degree. 


\begin{tabular}{|c|c|c|c|c|c|c|}
\hline \multicolumn{7}{|c|}{ Table 3 -Ego-Networks Measures } \\
\hline Egos & $\begin{array}{l}\text { David } \\
\text { Zwirner }\end{array}$ & Isa Genzken & $\begin{array}{l}\text { Wolfgang } \\
\text { Tillmans }\end{array}$ & $\begin{array}{l}\text { Luc } \\
\text { Tuymans }\end{array}$ & $\begin{array}{l}\text { Yayoi } \\
\text { Kusama }\end{array}$ & Jeff Koons \\
\hline Nodes & 6 & 9 & 6 & 3 & 5 & 9 \\
\hline Ties & 5 & 8 & 5 & 2 & 4 & 16 \\
\hline Degree & 1.667 & 1.778 & 1.667 & 1.333 & 1.6 & 3.556 \\
\hline Density & 0.333 & 0.222 & 0.333 & 0.667 & 0.4 & 0.444 \\
\hline $\begin{array}{l}\text { Avg. Path } \\
\text { Length } \\
\text { Avg. }\end{array}$ & 1.667 & 1.778 & 1.667 & 1.333 & 1.6 & 1.556 \\
\hline $\begin{array}{l}\text { Clustering } \\
\text { Coefficient }\end{array}$ & 0 & 0 & 0 & 0 & 0 & 0.788 \\
\hline Authority & 0.0512820 & 0.36 & 0.6593497 & 0.42855714 & 0.3846154 & 0.23076923 \\
\hline
\end{tabular}

\begin{tabular}{|c|c|c|c|c|c|c|}
\hline \multicolumn{7}{|c|}{ Table 4 - Weighted Ties: The Right Connections } \\
\hline & $\begin{array}{l}\text { David } \\
\text { Zwirner }\end{array}$ & Isa Genzken & $\begin{array}{l}\text { Wolfgang } \\
\text { Tillmans }\end{array}$ & $\begin{array}{l}\text { Luc } \\
\text { Tuymans }\end{array}$ & $\begin{array}{l}\text { Yayoi } \\
\text { Kusama }\end{array}$ & Jeff Koons \\
\hline Ties & 5 & 8 & 5 & 2 & 4 & 8 \\
\hline $\begin{array}{l}\text { Total of } \\
\text { weighted ties }\end{array}$ & 318 & 552 & 366 & 148 & 314 & 619 \\
\hline $\begin{array}{l}\text { Avg. } \\
\text { Weighted ties }\end{array}$ & 63.60 & 69.00 & 73.20 & 74.00 & 78.50 & 77.38 \\
\hline Power 100 \# & 3 & 37 & 11 & 67 & 53 & 14 \\
\hline
\end{tabular}

Notes: Weighted ties were calculated using the ranking of figures that are directly connected to the ego; the higher the figures' positions, the higher the scores.

There are several approaches to understanding the connecting ego role in the neighborhood and its positional advantage. Authority, as measured by Gephi and shown in Table 3, means that "actors who are more central to social structures are more likely to be influential or powerful (but possibly more constrained)". From this perspective, Genzken occupies the most central and powerful position. The artist is connected in a star network with many alters that rely on her to be connected to one another. Koons, on the other hand, has a much more connected web. This means that his position is not so favored and central.

The closest approach to the notion of social capital that is being investigated in this article is the actor's degree-based analysis. Hanneman \& Riddle argue that having more connections or relations with the "right" others may be an advantage. From this point of view, being connected to top ranked figures would grant the egos better scores. However, as Mark Rappolt, the 
ArtReview Editor, explains, ${ }^{6}$ having influence on what kind of art is shown is the most important criteria for being on the list, thereby making the artists' prominence lower than that of other figures. Therefore, the relations among different categories (artists, gallerists, etc.) are difficult to measure in a weighted approach (Table 4) and there is no clear relation with this and the position held by the figures.

\section{CONCLUSIONS}

This article analyzes the social relations among the most powerful and influential figures in the contemporary art world. We understand that the cultural production and distribution field operates as an organized and articulated system with strategic mechanisms of legitimation. In this context, social capital plays an eminent role in determining one's position in the field.

The social assets are engaged in networks of collaborative action and disputes over prestige among people and institutions. Thus, our aim has been to describe the social ties that guarantee artistic legitimation and that influence the perception of one's social value. The analysis shows that there are several players that can determine one's consecration in the field, as Mark Rappolt, the ArtReview Editor, explains:

[...] Someone doesn't get a show at the MoMA or the Tate just because they're the best artist in the world. There are a number of different interests that come together for that artist - it could be collectors, galleries, curators - and the list is designed to show how that might work and to show to some degree what those interests might be. And I think, increasingly, that affects the kind of art that gets shown and the kind of art that doesn't. If I was an artist based in Sarawak in Borneo, I might very well be the best artist that the world has ever seen, but no one's going to see my work. ${ }^{7}$

We have designed and analyzed the structure and characteristics of six sample egonetworks in order to recognize social patterns and identify the apparatuses that affect the cultural outcomes of the artistic world. The ego-networks that were examined in this article disclose the importance of commercial connections for the figures already considered legitimate and powerful. The art world can be seen as an ecosystem in which all the parties are interconnected and each activity can reverberate in the disposition of the field.

\footnotetext{
${ }^{6}$ Interview with Artreview Editor-in-Chief Mark Rappolt on the Power 1002014 Ranking published on Arsty: https://www.artsy.net/article/editorial-an-inside-look-at-artreviews-2014-power. Access in $27^{\text {th }}$ Feb 2016. ${ }^{7}$ Ibid.
} 
One of the limitations of this project is the selected database's scope and range. Although the amount of information available is significant, it does not cover all the works and main figures in contemporary art, nor the relations among them. This has been an obstacle for this study since several connections were not considered and might have biased the final results. The Artsy platform also excludes some non-market oriented and non-Western figures and institutions. Another constraint was that personal, non-commercial, and subjective relations were also not included.

These drawbacks, however, open future research possibilities. It could be useful to design and analyze a whole network from the Artsy archive based on the Power 100 ranking. A comparative ego-network study among databases could also investigate the impartiality of the information used here. A historical examination of the fourteen lists from 2002 to 2015 could show tendencies and dynamic characteristics about the mechanisms of the art field. In addition, a survey of the financial aspects of the most influential people in the artworlds could indicate some relations among their power and their economic capital.

\section{BIBLIOGRAPHY}

BECKER, H. S. Los mundos del arte: sociología del trabajo artístico. Bernal: Universidad Nacional de Quilmes, 2008.

. Mundos Artísticos e Tipos Sociais. In VELHO, G. Arte e Sociedade: ensaios de sociologia da arte (pp. 9-26). Rio de Janeiro: Zahar Editores, 1977.

BORGATTI, S. P., \& LOPEZ-KIDWELL, V. Network Theory. In The SAGE Handbook of Social Network Analysis. London: SAGE Publisher, 2011. P. 40-54.

BOURDIEU, P. A Distinção: crítica social do julgamento. Porto Alegre: Zouk, 2011.

. The production of belief: contribution to an economy of symbolic goods. Trans. Richard Nice. Media, Culture and Society, 2, 1980. P. 261-293.

A Produção da crença: contribuição para uma economia dos bens simbólicos. In

BOURDIEU, P. A Produção da crença: contribuição para uma economia dos bens simbólicos. Porto Alegre: Zouk, 2008.

But who created the 'creators'? In BOURDIEU, P. Sociology in Question. London:

Sage, 1993. P. 96-103. 
BURT, R. S. The netowrk structure of social capital. Organizational Behaviour, 22, 2000. P. 345-423.

DIMAGGIO, P. Cultural entrepeneurship in nineteenth-century Boston: the creation of an organizational base for high culture in America. Media, Culture and Society, 4, 1982. P. 33-50.

. Cultural Networks. In The SAGE Handbook of Social Network Analysis. London: SAGE Publisher, 2011. P. 286-300.

HANNEMAN, R. A., \& RIDDLE, M. Concepts and Measures for Basic Network Analysis. In SCOTT, J. \& CARRINGTON, P. J. (Eds.). The SAGE Handbook of Social Network Analysis. London: SAGE Publications, 2011. P. 340-369.

PÉNET, P., \& LEE, K. Prize \& price: The Turner Prize as a valuation device in the contemporary art market . Poetics , 43, 2014. P.149-171.

\section{APPENDIXES}

\begin{tabular}{|c|c|c|c|c|c|}
\hline \multicolumn{6}{|c|}{ Appendix 1 - General Information about Power 1002015 figures } \\
\hline Nationality & $n$ & $\%$ & Continent Of Birth & $n$ & $\%$ \\
\hline American & 30 & $25 \%$ & Africa & 5 & $4 \%$ \\
\hline British & 16 & $13 \%$ & Asia & 18 & $15 \%$ \\
\hline German & 14 & $11 \%$ & Europe & 59 & $48 \%$ \\
\hline Italian & 7 & $6 \%$ & South America & 7 & $6 \%$ \\
\hline French & 6 & $5 \%$ & Central America & 3 & $2 \%$ \\
\hline Swiss & 5 & $4 \%$ & North America & 30 & $25 \%$ \\
\hline Brazilian & 4 & $3 \%$ & Australia & 0 & $0 \%$ \\
\hline Chinese & 3 & $2 \%$ & Total $*$ & 122 & $100 \%$ \\
\hline Mexican & 3 & $2 \%$ & & & \\
\hline South African & 3 & $2 \%$ & & & \\
\hline Austrian & 2 & $2 \%$ & & & \\
\hline Bangladeshi & 2 & $2 \%$ & Gender & $n$ & $\%$ \\
\hline Belgian & 2 & $2 \%$ & Female & 36 & $30 \%$ \\
\hline Hong Kong & 2 & $2 \%$ & Male & 86 & $70 \%$ \\
\hline Indian & 2 & $2 \%$ & Total $*$ & 122 & $100 \%$ \\
\hline Japanese & 2 & $2 \%$ & & & \\
\hline Lebanese & 2 & $2 \%$ & & & \\
\hline Russian & 2 & $2 \%$ & & & \\
\hline South Korean & 2 & $2 \%$ & Top $10 \quad$ Residential & & \\
\hline Arab & 1 & $1 \%$ & Commercial Locations & $n$ & $\%$ \\
\hline Argentinian & 1 & $1 \%$ & 1 New York & 29 & $19 \%$ \\
\hline Cameroonian & 1 & $1 \%$ & 2 London & 16 & $11 \%$ \\
\hline Colombian & 1 & $1 \%$ & 3 Berlin & 13 & $9 \%$ \\
\hline
\end{tabular}




\begin{tabular}{llllll} 
Danish-Icelandic & 1 & $1 \%$ & 4 Paris & 8 & $5 \%$ \\
Greek & 1 & $1 \%$ & 5 Los Angeles & 8 & $5 \%$ \\
Nigerian & 1 & $1 \%$ & 6 Beijing & 7 & $5 \%$ \\
Polish & 1 & $1 \%$ & 7 Hong Kong & 6 & $4 \%$ \\
Qatari & 1 & $1 \%$ & 8 São Paulo & 4 & $3 \%$ \\
Serbian & 1 & $1 \%$ & 9 Zurich & 3 & $2 \%$ \\
Singaporean & 1 & $1 \%$ & 10 Tokyo & 3 & $2 \%$ \\
Spanish & 1 & $1 \%$ & Top 10 Total & 97 & $64 \%$ \\
Venezuelan & 1 & $1 \%$ & Locations Total * & 152 & \\
Total & 122 & $100 \%$ & City Quantity & 56 & \\
\hline
\end{tabular}

$*$ The total quantity is bigger than 100 , because we considered people and locations individually 


\begin{tabular}{|c|c|c|c|c|c|}
\hline \multicolumn{6}{|c|}{ Appendix 2 -Ego-Networks Nodes Information } \\
\hline & $\begin{array}{l}\text { Power } \\
100 \#\end{array}$ & Category & Nationality & Work and/or Residence & Institution \\
\hline David Zwirner & 3 & Gallerist & American & New York/ London & $\begin{array}{l}\text { David Zwirner } \\
\text { Gallery }\end{array}$ \\
\hline Isa Genzken & 37 & Artist & German & Berlin & - \\
\hline Luc Tuymans & 67 & Artist & Belgian & Antwerp & - \\
\hline $\begin{array}{r}\text { Wolfgang } \\
\text { Tillmans }\end{array}$ & 11 & Artist & German & Berlin/ New York & - \\
\hline Yayoi Kusama & 53 & Artist & Japanese & Tokyo & - \\
\hline Jeff Koons & 14 & Artist & American & New York & - \\
\hline $\begin{array}{r}\text { Iwan \& Manuela } \\
\text { Wirth }\end{array}$ & 1 & Gallerist & Swisses & $\begin{array}{l}\text { Zurich / London / New } \\
\text { York / Somerst }\end{array}$ & Hauser \& Wirth \\
\hline Beatrix Ruf & 22 & Curator & German & Amsterdam & $\begin{array}{l}\text { Stedelijk Museum } \\
\text { Amsterdam }\end{array}$ \\
\hline $\begin{array}{r}\text { Matthew } \\
\text { Slotover \& } \\
\text { Amanda Sharp }\end{array}$ & 49 & $\begin{array}{l}\text { Art Fair } \\
\text { Director }\end{array}$ & Britons & New York/ London & Frieze Art Fair \\
\hline $\begin{array}{r}\text { Tim Neuger \& } \\
\text { Burkhard } \\
\text { Riemschneider }\end{array}$ & 78 & Gallerist & Germans & Berlin & $\begin{array}{l}\text { Galerie } \\
\text { Neugerriemschneider }\end{array}$ \\
\hline Daniel Buchholz & 40 & Gallerist & German & $\begin{array}{l}\text { Cologne / Berlin / New } \\
\text { York }\end{array}$ & Buchholz Galerie \\
\hline Okwui Enwenor & 17 & Curator & Nigerian & New York / Munich & $\begin{array}{l}\text { 56th Venice Biennal } \\
(2015)\end{array}$ \\
\hline Bernard Arnault & 38 & Collector & French & Paris & $\begin{array}{l}\text { Fondation Louis } \\
\text { Vitton }\end{array}$ \\
\hline $\begin{array}{r}\text { Hans Ulrich } \\
\text { Obrist \& Julia } \\
\text { Peyton-Jones }\end{array}$ & 4 & $\begin{array}{l}\text { Museum } \\
\text { Directors }\end{array}$ & $\begin{array}{l}\text { Swiss / } \\
\text { British }\end{array}$ & London & Serpetine Galleries \\
\hline $\begin{array}{r}\text { Eli \& Edythe } \\
\text { Broad }\end{array}$ & 28 & Collectors & Americans & Los Angeles & The Broad \\
\hline Larry Gagosian & 6 & Gallerist & American & $\begin{array}{l}\text { New York / Paris / Athens / } \\
\text { London / Beverly Hills / } \\
\text { Rome / Hng Kong / Gevea }\end{array}$ & Gagosian Gallery \\
\hline François Pinault & 33 & Collector & French & Paris & $\begin{array}{l}\text { Pallazo Grassi; } \\
\text { Christie's }\end{array}$ \\
\hline Adam Weinberg & 9 & $\begin{array}{l}\text { Museum } \\
\text { Director }\end{array}$ & American & New York & Whitney Museum \\
\hline $\begin{array}{r}\text { Christopher } \\
\text { Wool }\end{array}$ & 59 & Artist & American & New York / Marfa & - \\
\hline Cindy Sherman & 41 & Artist & American & New York & - \\
\hline Ai Weiwei & 2 & Artist & Chinese & Beijing & - \\
\hline
\end{tabular}

